\title{
Redescription of Moenkhausia doceana (Steindachner, 1877) (Ostariophysi: Characiformes): a characid from the Northeastern Mata Atlântica ecoregion, Brazil
}

\author{
Fernando R. Carvalhoํㅜ Luisa M. Sarmento-Soares ${ }^{2,3}$ and Ronaldo F. Martins-Pinheiro²
}

Moenkhausia doceana is redescribed from the Northeastern Mata Atlântica ecoregion drainages in Espírito Santo, Minas Gerais, and Bahia states. The species is distinguished from its congeners by a long anal fin, with 29-34 (mode 32) branched rays; 4-7 (mode 5) maxillary teeth; and 7-8 (mode 7) scale rows above lateral line at dorsal-fin origin. Phylogenetic hypothesis about its relationships among the Characidae is also presented and commented.

Moenkhausia doceana é redescrita das drenagens da ecorregião Mata Atlântica Nordeste nos estados do Espírito Santo, Minas Gerais e Bahia. A espécie distingue-se das demais congêneres por apresentar uma nadadeira anal longa, com 29-34 (moda 32) raios ramificados; 4-7 (moda 5) dentes maxilares e 7-8 séries horizontais de escamas acima da linha lateral até a origem da nadadeira dorsal. Hipótese filogenética sobre suas relações em Characidae é também apresentada e comentada.

Key words: Characidae, Lambari, Rio Doce, Systematics, Tetragonopterus.

\section{Introduction}

Moenkhausia Eigenmann, with 76 valid species, is a species-rich genus of the Characidae (sensu Mirande, 2010). Together with Astyanax Baird \& Girard, Hemigrammus Gill, and Hyphessobrycon Durbin, they represent around 35\% of characid species. Moenkhausia species are widespread in the Neotropical cis-Andean river basins, and its largest diversity is in the Amazon and Guyana basins (Lima et al., 2003; Eschmeyer, 2014). The group includes small (e.g., $M$. newtoni Travassos; maximum length: $27.0 \mathrm{~mm}$ Standard Length - SL) and relatively large species (e.g., M. tridentata Holly; $118.1 \mathrm{~mm} \mathrm{SL}$ ), although the average size of species is around $60 \mathrm{~mm}$ SL, with broad range in overall body shape and color pattern.

In spite of Moenkhausia being regarded as a nonmonophyletic genus (Mirande, 2010; Mariguela et al., 2013), and in the absence of a phylogenetic analysis available at the moment, the genus is still recognized in a traditional combination of characters presented by Eigenmann (1917), e.g., caudal fin at least partly covered with small scales; lateral line complete; second suborbital (third infraorbital sensu Weitzman, 1962) leaving a naked area dorsal to the lower limb of preopercle; at least five teeth in the inner row of the premaxillary. Moreover, Eigenmann (1917) was the only author to present a unique complete taxonomic revision for the genus, at that moment with 29 species.

Approximately one-half of the species ascribed to Moenkhausia were described in the first half of the $20^{\text {th }}$ century. Many of these were poorly diagnosed and little is known about their distributions. Within this context, we herein provide a redescription of Moenkhausia doceana (Steindachner), a taxon distributed in the coastal drainages of Espírito Santo, Minas Gerais, and Bahia states (Northeastern Mata Atlântica ecoregion sensu Abell et al., 2008) to help in clarifying the taxonomic status within the genus. Comments about its relationships in the Characidae are also presented and commented.

\footnotetext{
${ }^{1}$ UNESP, Universidade Estadual Paulista “Júlio de Mesquita Filho”, Instituto de Biociências, Letras e Ciências Exatas, Departamento de Zoologia e Botânica, Laboratório de Ictiologia. Programa de Pós-Doutoramento da UNESP. Rua Cristóvão Colombo, 2265, Jardim Nazareth, 15054-000 São José do Rio Preto, SP, Brazil. frcarvalho2004@yahoo.com.br

${ }^{2}$ Museu de Biologia Prof. Mello Leitão. Avenida José Ruschi, 4, Centro, 29650-000 Santa Teresa, ES, Brazil. luisa@nossosriachos.net , pinheiro.martins@gmail.com

${ }^{3}$ Programa de Pós-Graduação em Biologia Animal, Universidade Federal do Espírito Santo.

Avenida Marechal Campos, 1468, Prédio da Biologia, câmpus de Maruípe, 29043-900 Vitória, ES, Brazil.
} 


\section{Material and Methods}

Measurements and counts were taken as described by Fink \& Weitzman (1974) and Carvalho et al. (2010). Measurements were made with a digital caliper to the nearest $0.05 \mathrm{~mm}$ on the left side of the specimen whenever possible, and are presented as percents of standard length (SL), except subunits of the head, which are given as percents of head length (HL). In the description, counts of non-type specimens are followed by their frequency in parentheses, and values between brackets indicate counts of the syntypes. Counts of vertebrae, supraneurals, gill-rakers on the first branquial arch, branchiostegal rays, procurrent caudal-fin rays, dentary teeth, and number of cusps were taken from four c\&s specimens prepared according to Taylor \& Van Dyke (1985). Vertebral count includes the four vertebrae in the Weberian apparatus and also the fused $\mathrm{PU} 1+\mathrm{U} 1$ of the caudal region as a single element. The pattern of circuli and radii was defined on scales sampled from the region between the lateral line and the insertion of pelvicfin. Comparisons and data of Moenkhausia species not available for examination were taken from the literature (original descriptions). In "Material examined" catalog numbers are followed by the total number of specimens, number of specimens measured and counted in parentheses, and SL range of all specimens (including c\&s specimens, if any) of the lot, when possible. Stomach contents of some preserved specimens in alcohol solution $70^{\circ}$ were analyzed. Institutional abbreviations follow Reis et al. (2003), with addition of CIUFES, Coleção Ictiológica da Universidade Federal do Espírito Santo, Vitória; MBML, Museu de Biologia Professor Mello Leitão, Santa Teresa; UFBA, Universidade Federal da Bahia, Salvador; UFRGS, Departamento de Zoologia, Universidade Federal do Rio Grande do Sul, Porto Alegre; ZMA, Zoologisch Museum Amsterdam, now in RMNH, National Natuurhistorisch Museum, The Naturalis Biodiversity Center, Leiden.

A phylogenetic analysis was performed using TNT software (Goloboff et al., 2008), adding Moenkhausia doceana to the matrix of Mirande (2010) and modified by Carvalho et al. (2014). The analysis included implied weighting, following the same procedures described by Mirande (2009, 2010), and 21 values of " $k$ " were used under each of the weighting schemes. Character states for $M$. doceana are given in Table 1 . The numbers for each character follow Mirande (2010).

Table 1. Character states of Moenkhausia doceana. Character list is the same of Mirande (2010); polymorphisms [01] are represented as "a".

\begin{tabular}{|c|c|c|c|c|}
\hline 00110010?1 & 0011000100 & 0001100001 & 0000100001 & 0000011a00 \\
\hline 0a00000000 & 0000000011 & ?010000000 & 0000000110 & 0101000010 \\
\hline 0010000001 & 1000000100 & 0100011010 & $00011101 \mathrm{a} 0$ & 001?000100 \\
\hline 1010000000 & 0000000101 & 0001000110 & 0101000101 & 0001100000 \\
\hline 0111000010 & 0100000101 & 0100000100 & 1001000000 & 0000000001 \\
\hline 0101000100 & 0001110001 & 1000010000 & 0000111100 & 0000010101 \\
\hline 0000101110 & 0000010011 & 2100000110 & 0001110000 & 1100000000 \\
\hline 00?0?00??? & ????? & & & \\
\hline
\end{tabular}

\section{Results}

\section{Moenkhausia doceana (Steindachner, 1877) Figs. 1-5}

Tetragonopterus doceanus Steindachner, 1877: 572-575. Type locality: rio Doce.

Moenkhausia doceana (Steindachner): -Eigenmann, 1910: 437 (listed). -Eigenmann, 1917: 66; 73-75 (short redescription of species, but without analysis of syntypes ). -Zarske \& Géry, 2001: 5-13 (comparison to M. margitae and data of some syntypes). -Zarske \& Géry, 2002: 52 (comparison to M. dorsinuda). -Lima et al., 2003: 148 (listed). -Bertaco \& Lucinda, 2006: 65, 66 (comparison to M. pankilopteryx). Lima et al., 2007: 58 (listed).

Diagnosis. Moenkhausia doceana is promptly distinguished from all congeners [except $M$. affinis (Steindachner), $M$. barbouri Eigenmann, M. dorsinuda Zarske \& Géry, M. jamesi Eigenmann, $M$. justae Eigenmann, M. latissima Eigenmann, M. levidorsa Benine, $M$. margitae Zarske \& Géry, M. moisae Géry, Planquette \& Le Bail, M. newtoni, M. simulata (Eigenmann), M. tergimacula Lucena \& Lucena] by a long anal fin, with 29-34 (mode 32) branched rays (vs. 28 or less in others species). Moenkhausia doceana differs from the aforementioned species, except $M$. tergimacula, by having 4-7 (mode 5) maxillary teeth (vs. 3 or less). Lastly, M. doceana differs of $M$. tergimacula by having 7-8 (mode 7) scale rows above lateral line and no marks anteriorly to dorsal-fin origin (vs. 51/2 scales rows above lateral line and presence of a distinct dark, saddle-like mark on the body immediately anterior to dorsal-fin origin).

Description. Morphometric data are summarized in Table 2. Body compressed, moderately long and high, greatest body depth at vertical through dorsal-fin origin. Dorsal profile of head convex from tip of upper jaw to vertical through anterior nostril; slightly concave or straight from that point to tip of supraoccipital spine. Dorsal profile of body slightly convex from posterior tip of supraoccipital spine to base of first dorsalfin ray, and straight that point to adipose-fin origin. Ventral profile of body convex from tip of lower jaw to pelvic-fin origin, straight or slightly convex from that point to anal-fin origin, and straight and posterodorsally slanted along of analfin base. Dorsal and ventral profile of caudal peduncle straight to slightly concave.

Mouth terminal, premaxillary and dentary approximately the same size. Maxilla extending posteroventrally to first onethird of orbit, almost reaching tip of second infraorbital, approximately at 45 degrees angle relative to longitudinal axis of body. Main axis of maxilla straight, with approximately same width along entire length. Nostrils close to each other, anterior opening small and circular, posterior opening twice in size and reniform. Nostrils separated by skin flap when adpressed, almost covering the posterior nostril. Frontals not united anteriorly, with a triangle-shaped fontanel; parietal fontanel 


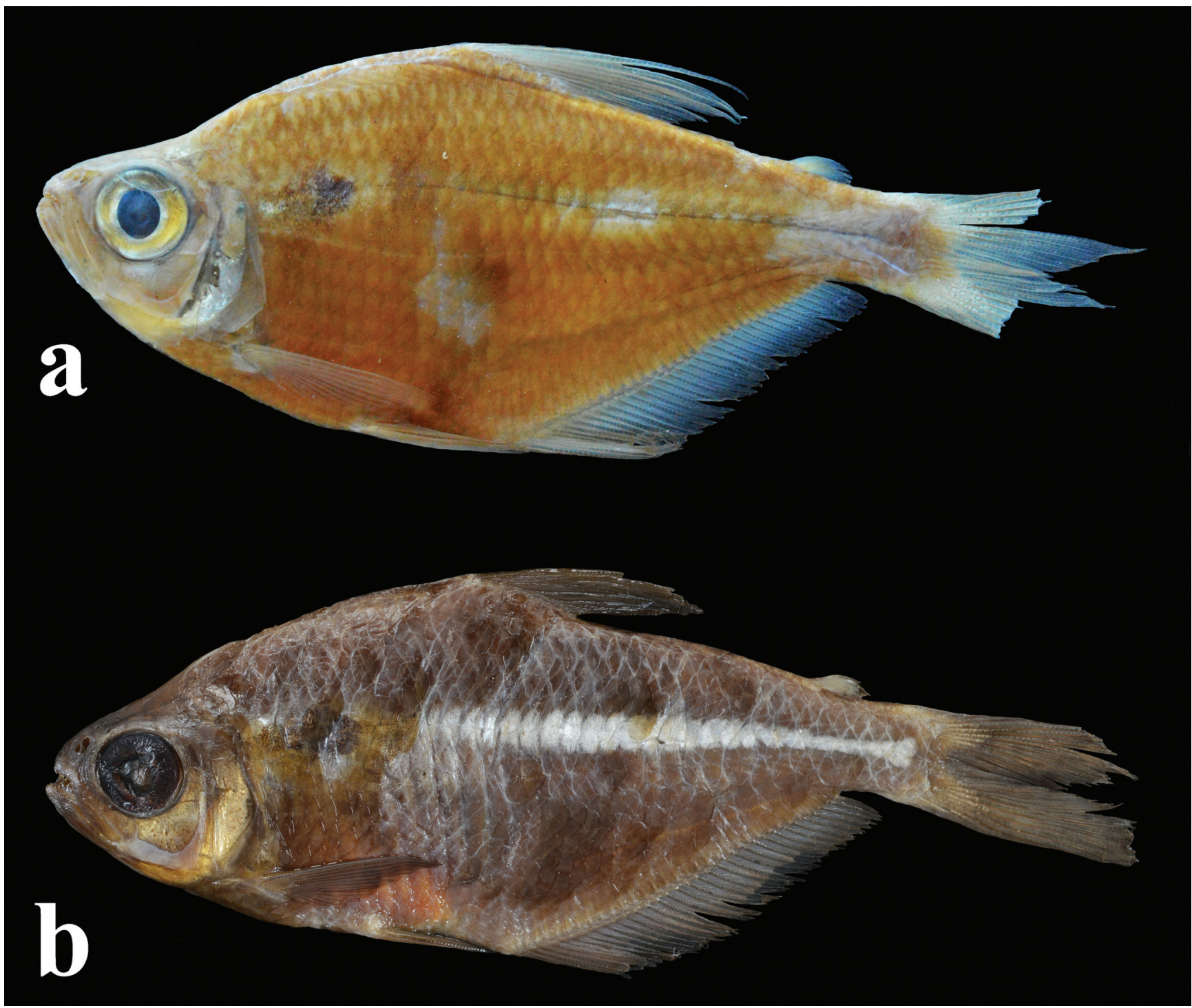

Fig. 1. Tetragonopterus doceanus, syntypes, (a) MHNH 1913.136, 62.2 mm SL, and (b) NMW 57391, 83.8 mm SL, rio Doce, Brazil.

large, extending from epiphyseal bar to supraoccipital spine. Eyes relatively large, without adipose eyelid. Infraorbital bones complete, with six elements (Fig. 4). Laterosensory canal from first to sixth infraorbital close to inner margin of orbital rim. Third infraorbital largest, approximately twice the size of others (except second), with inferior margin slightly straight (Fig. 4), not contacting the laterosensory canal of preopercle ventrolaterally.

Two tooth rows in the premaxilla: outer row with 4(13), 5(48), or 6(6) [4(4) or 5(2)] tricuspid teeth; inner row with 5(34) or 6(33) [5(6)], pentacuspid teeth. Dentary with 4(42) or 5(14) [4(3) or 5(3)] large, pentacuspid teeth, followed by a series of 10(1), 11(1), or 13(2) conical or triscupid teeth, abruptly smaller than the or five anterior largest teeth. Dorsal border of maxilla relatively straight. Maxilla with 4(12), 5(36), 6(15), or 7(7) [4(1), 5(3), or 6(2)] tri- or tetracuspid teeth along anteroventral margin (Fig. 5). Central median cusp of all teeth longer than remaining lateral cusps; cusps tips slightly curved inwardly on dentary and premaxillary teeth.

Scales cycloid, with few radii (2-6), relatively small; circuli marked anteriorly and marginally (dorsal and ventral). Lateral line complete, extending from the superior portion of opercular opening to beginning of caudal fin with 34(2), 35(31), 36(29), 37(2), or 38(1) [34(2), 35(2), or 36(2)] perforated scales; horizontal scales rows between dorsal-fin origin and lateral line 7(23), 71/2(10), or 8(37) [7(1) or 8(3)]; horizontal scales rows between lateral line and pelvic-fin origin 6(4), 61/2(4), or 7(49) [6(1), 61/2(1), or 7(2)]. Predorsal scales 10(20) or 11(13) [10(2) or 11(4)]. Scale sheath along anal-fin base 14(3), 15(2), 16(8), 17(4), 18(2), or 19(2) [15(1) or 16(1)] in a single row. Circumpeduncular scales 14(33) or 15(12) [14(4) or 15(1)]. Axillary scale present, covering two scales posteriorly, distinctly triangular-shaped, thinner on posterior tip.

Dorsal fin rays ii,9(77) [ii,9(6)]; first unbranched ray 


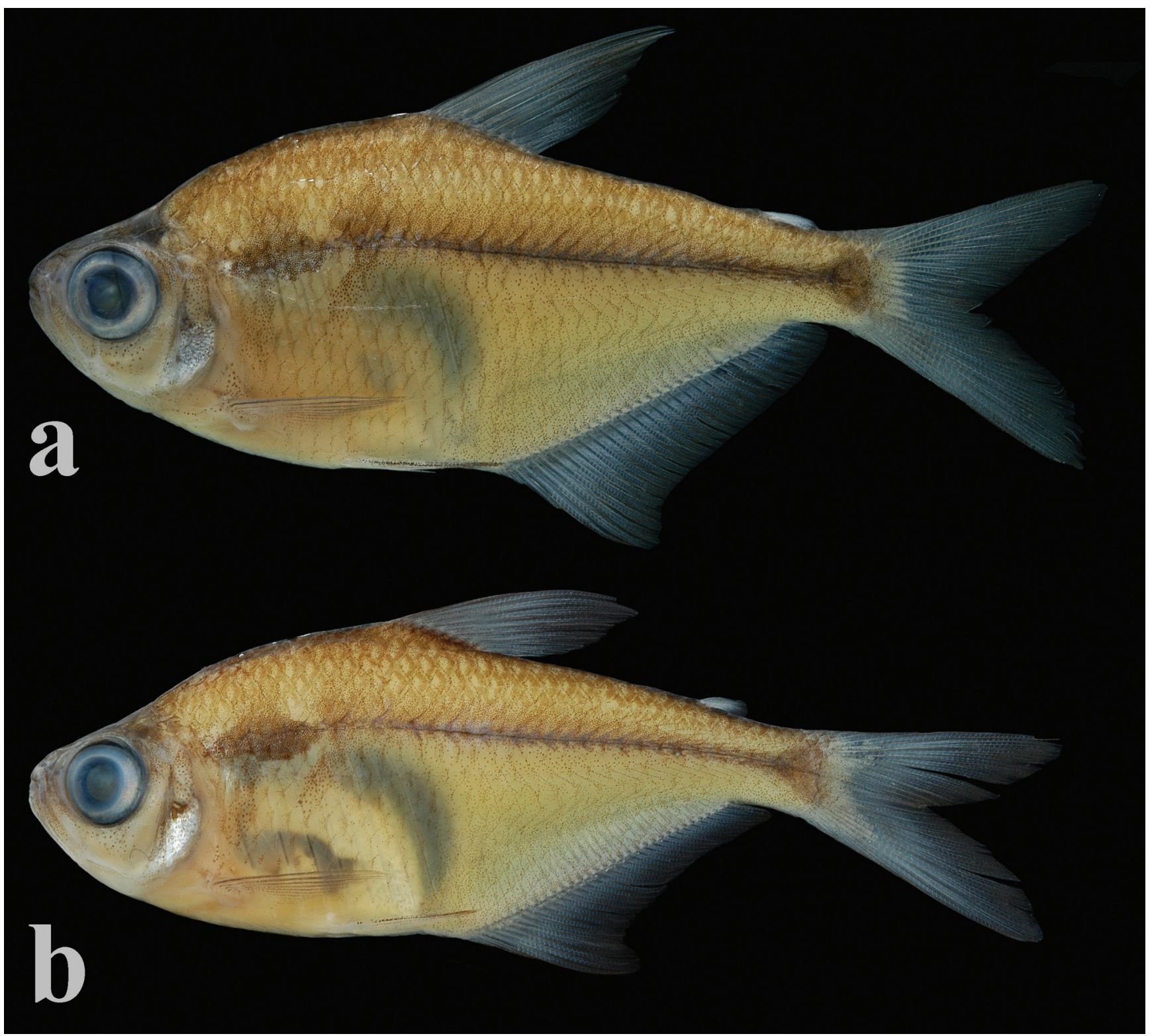

Fig. 2. Moenkhausia doceana, MBML 3831, (a) male, 68.9 mm SL, and (b) female, 62.7 mm SL.

approximately half the length of second one or shorter. Dorsalfin origin slightly forward on midbody, at vertical through anterior one-third of pelvic-fin origin. Base of last dorsal-fin ray at vertical through distal tip of longest pelvic-fin ray, anterior to origin of anal fin. Tip of longest ray of adpressed dorsal fin at vertical through base of first two branched analfin rays. First dorsal-fin pterygiophore inserted between neural spine of eighth and ninth precaudal vertebra. Adipose fin present, well-developed. Pectoral fin with i,11(2), 12(15), $13(51)$, or $14(3)$ [i,12(3) or i,14(3)]; longest ray extending to one-third of pelvic-fin origin. Pelvic fin with i,7(77) [i,7(6)] rays. Pelvic-fin origin located anterior to vertical through dorsal-fin origin and with small bony hooks in mature males, absent in females. Tip of longest pelvic-fin ray reaching up to second or third branched ray anal-fin ray when adpressed. Anal-fin rays iv,29(2), 30(1), 31(10), 32(26), 33(23), or 34(6)
[31(3), 32(2), or 33(1)]. Caudal fin forked, lobes slightly rounded or pointed, upper lobe slightly smaller than lower lobe, with i,9/8,i(77) [i,9/8,i(6)] rays. Caudal fin scaled, scales over base and along lower caudal-fin lobe up to middle; upper lobe with few scales, extending to its anterior one-third; scales gradually decreasing posteriorly in size. Dorsal procurrent caudal-fin rays $9(1), 10(1)$, or $11(2)$, and ventral procurrent caudal-fin rays $7(2)$, or $8(2)$.

Branchiostegal rays 4(4). First gill arch with 8(4) gill rakers on epibranchial, 1(4) between epibranchial and ceratobranchial, 10(3) or 11(1) on ceratobranchial, and 2(4) on hypobranchial. Denticles on gill rakers present. Precaudal vertebrae 15(4) and caudal vertebrae 19(2) or 20(2). Total vertebrae 34(2) or 35(2). Supraneurals 3(1) or 4(3), filiform, with dorsal portion expanded and some bifurcated dorsally. 


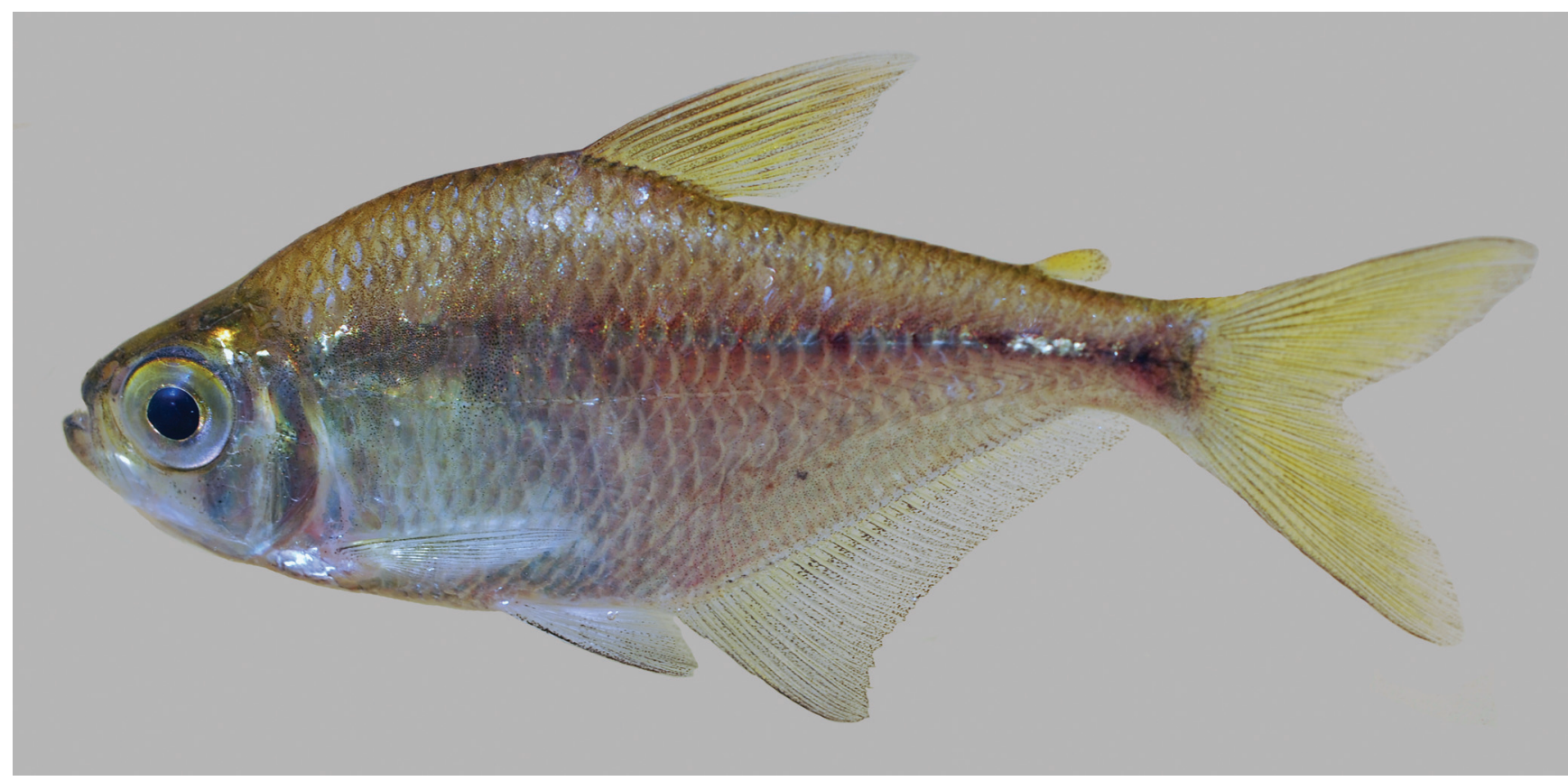

Fig. 3. Moenkhausia doceana, live specimen, not preserved.

Color in alcohol. Overall ground coloration yellowish, with light brown thin stripe extending longitudinally along lateral line from vertical through dorsal-fin origin to caudal peduncle. Head brownish dorsally, paler towards sides of head. Dark chromatophores concentrated on distal margin of scales resulting in reticulated pattern. Mid-dorsal region darker than flanks. Humeral region with horizontally rounded dark spot immediately above lateral-line scales, extending about two scales vertically and 4-6 scales horizontally. A second faint blotch behind humeral spot, comma shaped. Area above hypural plate with faint dark spot, almost triangle shaped. First rays of pelvic and anal fins with dark chromatophores, resulting in darker fin border. Dorsal fin with scattered dark chromatophores, more concentrated on anterior one-half. Anal fin with scattered dark chromatophores. Adipose-fin contour with dark chromatophores. Remaining fins hyaline on tips, with scattered dark chromatophores between unbranched rays (Fig. 2).

Color in life. The following description is based on the examination of freshly specimens recently caught along northern Espírito Santo and southern Bahia rivers. Ground color pale yellow to silver gray, darker dorsally. Sides of body somewhat silver colored anteriorly to light red posteriorly. Longitudinal inconspicuous brilliant stripe at level of lateral line, silvery colored in some specimens. Humeral region with a faint horizontally rounded spot, followed by a second comma shaped faint blotch. Eyes yellowish to whitish. Opercle and preopercle region silver colored; fins yellowish to translucent (Fig. 3). A faint brownish spot, almost triangle shaped on caudal peduncle.
Sexual dimorphism. Bony hooks on anal and pelvic fins, and also anal-fin profile distinguish males from females in Moenkhausia doceana. Mature males with very small bony hooks on the segments of the last unbranched and all branched anal-fin rays (one pair of bony hooks on posterior surface of hemitrichia), absents in females. Males with anal-fin distal margin slightly straight (Fig. 2a) while females with anal-fin distal margin falcate anteriorly (Fig. 2b). Gill glands (sensu Burns \& Weitzman, 1996) were not found macroscopically on first gill arch on both sexes.

Distribution. Moenkhausia doceana occurs along coastal river systems, with northern limits corresponding to the rio João de Tiba, on extreme southern Bahia river basins. The species is recorded until southern limits at the rio Riacho, a small coastal basin south of rio Doce in Espírito Santo State, and to the West in the middle rio Doce lake systems, rio Doce basin (Fig. 6). Known populations of $M$. doceana inhabit areas of mild relief, as in lakes of the rio Doce valley and along coastal drainages between Espírito Santo and southern Bahia states. The western portion of its distribution is within Coastal Tablelands area, a wide region with elevations usually not passing $150 \mathrm{~m}$, coinciding with the Cenozoic sediments of the Barreiras Group, well seen along the whole coastal distributional area. Despite its range distribution, no significant morphological and meristic differences were found among $M$. doceana populations, suggesting that the species corresponds to a single taxon in all coastal drainages where it occurs. Regarding global biogeography regionalization of freshwater systems, the pattern of distribution of $M$. doceana fits the Northeastern Mata Atlântica ecoregion (sensu Abell et al., 2008). 


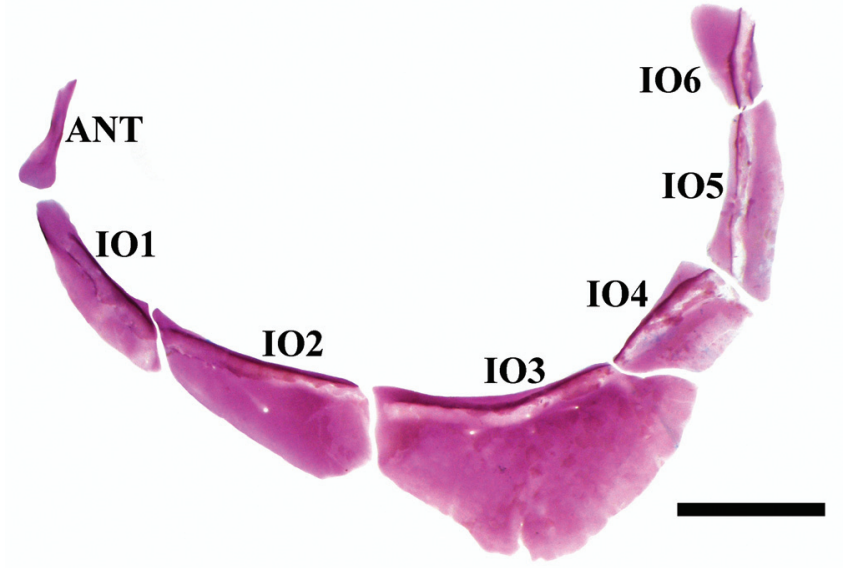

Fig. 4. Moenkhausia doceana, MBML 5883, 51.6 mm SL. Antorbital (ANT) and infraorbital bones (IO1-6); left lateral view. Scale bar $=2 \mathrm{~mm}$.

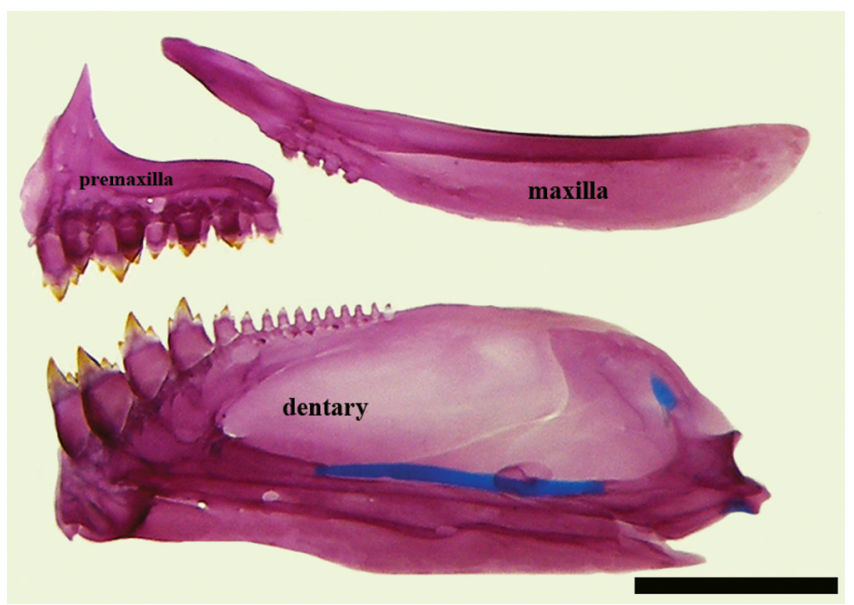

Fig. 5. Upper and lower jaws of Moenkhausia doceana, MBML 5883, 59.2 mm SL, left lateral view. Scale bar = 2 mm.

Ecological notes. Moenkhausia doceana inhabits second and third order streams, about two to three meters wide and 0.5 to 1.6 meters deep, characterized by clear water and moderate to fast current, sandy bottom with gravel, and riparian surrounding vegetation. The fishes were captured in the water column, mainly near the surface. It is an invertivore that eats aquatic insect larvae (e.g., Chironomidae), nymphs (e.g., Ephemeroptera), and fragments of terrestrial arthropods (ants, beetles, and spiders). Moenkhausia doceana occurs syntopically with Characidium aff. fasciatum Reinhardt, Hoplias malabaricus (Bloch), Astyanax aff. intermedius Eigenmann, Astyanax aff. lacustris (Lütken), Hyphessobrycon bifasciatus Ellis, Trichomycterus pradensis Sarmento-Soares, Martins-Pinheiro, Aranda \& Chamon, Corydoras nattereri Steindachner, Pimelodella aff. vittata (Lütken), Poecilia vivipara Bloch \& Schneider, and Geophagus brasiliensis (Quoy \& Gaimard) (Sarmento-Soares \& Martins Pinheiro, 2013). Moenkhausia doceana was recorded in conservation units such as the Parque Estadual do Rio Doce (PERD), Minas
Gerais (Ottoni et al., 2011), Reserva Biológica do Córrego Grande, Espírito Santo (Sarmento-Soares \& Martins-Pinheiro, 2013), and Reserva Biológica Sooretama, Espírito Santo (LMSS and RFMP, pers. obs.).

Popular name. Moenkhausia doceana is known as lambari (Lima et al., 2003) or piaba, in northern Espírito Santo and southern Bahia states.

Phylogenetic reconstruction. Phylogenetic analysis, according to implied weighting procedures (Mirande, 2009, 2010), with consensus of “ $k$ " = 10.07571802 (three trees) and "k" = 11.06353351 (three trees) values, resulted in one cladogram with 2263 steps, Consistency Index (CI) of 0.16 and Retention Index (RI) of 0.66.

Moenkhausia doceana is included in the Tetragonopterinae of Mirande (2010). It is sister group of (Tetragonopterus argenteus (Gymnocorymbus ternetzi (Stichonodon insignis (Poptella paraguayensis, Stethaprion erythrurus)))). Synapomorphies for this clade are: ch. 201:1 - denticles on gill rakers absent [reversed in $M$. doceana]; ch. 287:1 - 18 or more branched anal-fin rays; ch. 314:0 - bony hooks on last pelvic-fin ray of adult males absent; $\mathbf{c h}$. 341:1 - humeral spot horizontally-ovate. Autapomorphies for $M$. doceana are: ch. 22:0 - frontal fontanel present; ch. 63:0 anterior region of third infraorbital not much expanded relative to posterior region of second infraorbital; ch. 66:0 - fourth infraorbital present and well developed; ch. 82:0 - dorsal end

Table 2. Morphometric data for Moenkhausia doceana: syntypes (MNHN 1913-135, 1; MNHN 1913-136, 1; NMW 57389, 2; and NMW 57591, 2). $\mathrm{N}=$ number of non-type specimens, SD = Standard Deviation (not including syntype data).

\begin{tabular}{|c|c|c|c|c|c|}
\hline & \multicolumn{2}{|c|}{ Syntypes } & \multicolumn{3}{|c|}{ Non-type specimens } \\
\hline & Range & \multirow{2}{*}{$\frac{\text { Mean }}{71.1}$} & \multirow{2}{*}{$\frac{\text { Range }}{30.1-81.4}$} & \multicolumn{2}{|c|}{ Mean SD N } \\
\hline Standard Length (mm) & $57.8-83.8$ & & & 54.8 & -73 \\
\hline \multicolumn{6}{|c|}{ Percents of Standard Length } \\
\hline Body depth & $41.0-45.7$ & 44.0 & $37.0-45.8$ & 41.9 & \\
\hline Head length & $24.6-27.3$ & 26.1 & 16.6-30.9 & 26.7 & \\
\hline Head depth & $31.6-35.7$ & 33.6 & $27.0-35.7$ & 32.3 & 2.656 \\
\hline Predorsal length & 51.3-52.6 & 52.0 & 48.9-54.4 & 51.0 & 1.373 \\
\hline Prepelvic length & $42.1-45.0$ & 44.1 & 40.9-48.5 & 44.6 & 1.573 \\
\hline Pelvic fin to anal distance & $16.2-18.6$ & 17.0 & 13.3-21.5 & 16.3 & 1.470 \\
\hline Caudal peduncle $\mathrm{d}$ & $10.3-11.6$ & 10.7 & $7.8-1$ & 9.8 & 0.873 \\
\hline Dorsa & 13.6-14.3 & 13.9 & 12.4-17.1 & 14.2 & 0.873 \\
\hline Anal-fi & $41.0-44.0$ & 42.2 & $37.4-44.2$ & 41.0 & 1.573 \\
\hline Pecto & $20.5-24.0$ & 22.4 & $21.0-25.5$ & 23.0 & 0.972 \\
\hline Pelvic-fin length & $17.7-20.3$ & 19.2 & $16.3-22.1$ & 19.2 & 1.072 \\
\hline Dorsal-fin length & 29.5-34.2 & 31.9 & 28.4-35.2 & 32.2 & 1.771 \\
\hline Anal-fin length & $20.0-23.3$ & 21.7 & $18.4-25.3$ & 22.2 & 2.061 \\
\hline Caudal peduncle length & $9.9-11.7$ & 10.8 & $9.3-13.4$ & 11.0 & 0.973 \\
\hline Dorsal fin to adipose-fin distance & $40.1-42.6$ & 41.0 & $37.1-42.7$ & 40.0 & \\
\hline Eye to dorsal-fin origin & $36.1-39.3$ & 37.9 & $33.9-40.1$ & 36.4 & 1.473 \\
\hline Dorsal origin to caudal origin & $55.2-58.1$ & 56.5 & 50.3-59.8 & 56.4 & 1.473 \\
\hline \multicolumn{6}{|c|}{ Percents of head length } \\
\hline Interorbital width & $32.5-35.3$ & 33.9 & $27.5-36.1$ & 31.3 & 1.770 \\
\hline Snout length & $20.8-24.9$ & 23.1 & 21.9-29.3 & 24.8 & 1.965 \\
\hline Orbital diameter & $39.9-44.0$ & 42.3 & 40.6-48.5 & 44.6 & 1.9 \\
\hline Upper jaw length & 45.7-48.5 & 47.7 & $41.3-49.8$ & 47.3 & 1.941 \\
\hline
\end{tabular}




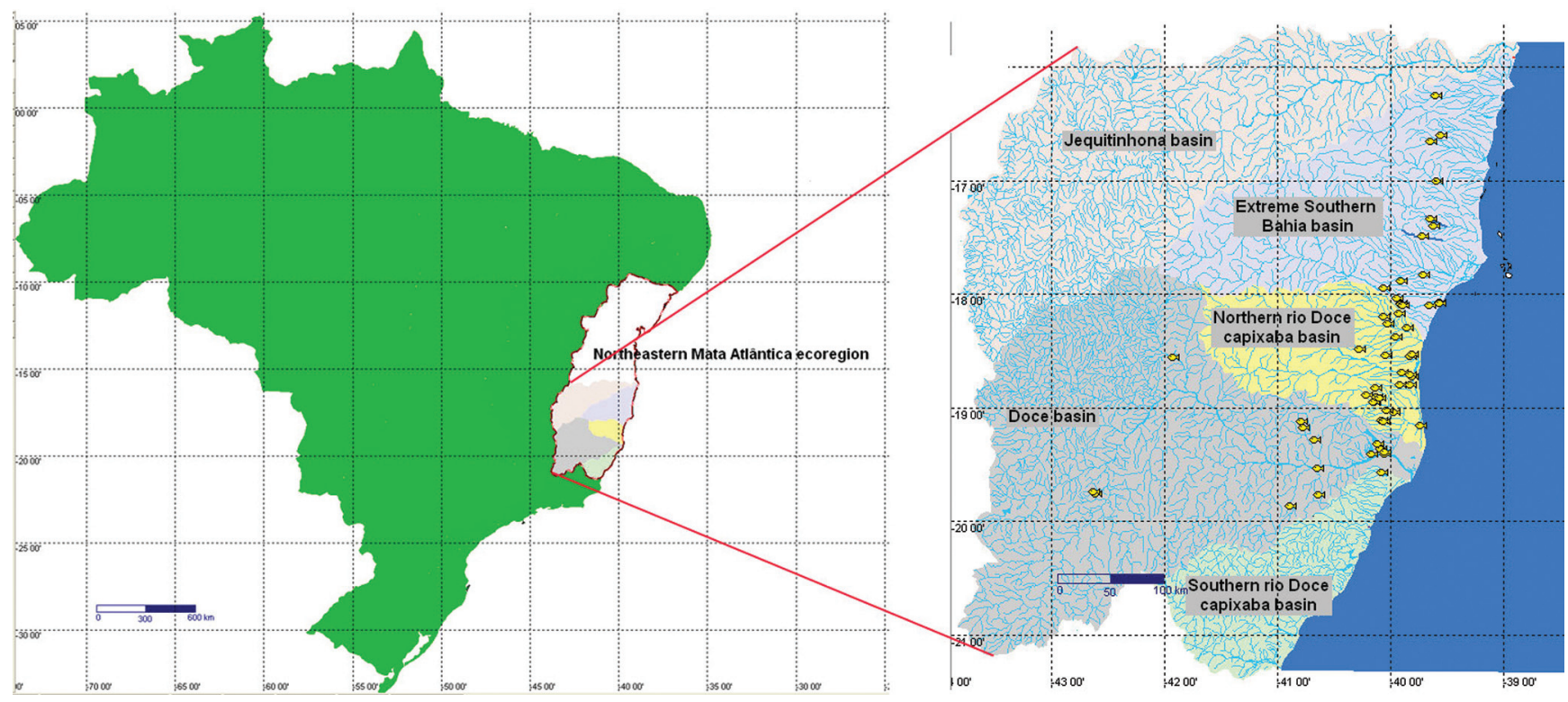

Fig. 6. Distribution of Moenkhausia doceana in Northeastern Mata Atlântica ecoregion. Each mark may represent more than one locality.

of laterosensory canal of preopercle and suprapreopercle not overlapping anterodorsal process of opercle; ch. 109:1 - ventral margin of horizontal process of anguloarticular perpendicular to laterosensory canal of dentary from medial view; ch. 135:1 - two or more maxillary teeth; ch. 225:0 abdominal ribs on anterior caudal vertebrae absent; $\mathbf{c h}$. 281:0 - seven or fewer supraneurals; ch. 305:0 - anterior ventral procurrent caudal-fin rays paired, only distally fused; ch. 315:1 - bony hooks on first pelvic-fin ray of adult males present; ch. 340:1 - insertion of pterotic aponeurosis on a lobe situated dorsal to horizontal semicircular canal.

Material examined. Syntypes. All from Brazil, rio Doce. Tetragonopterus doceanus, NMW 57389, 2(2), 57.8-70.0 mm SL. NMW 57591, 2(2), 83.3-83.3 mm SL. MNHN 1913-135, 1(1), 68.4 mm SL. MHNH 1913-136, 1(1), 62.2 mm SL. Moenkhausia doceana, Non-type specimens (ordered by river basin, and município). All from Brazil. Espírito Santo State, rio Riacho basin. Município de Aracruz. MBML 2728, 4, 57.4-65.0 mm SL (ex-CIUFES 130078), limit between Aracruz and Linhares, Lagoa do Aguiar. Espírito Santo State, rio Doce basin. Município de Colatina. MBML 678, 2(1), 21.7-30.1 mm SL, mouth of rio Santa Joana. MBML 3391, 1, $34.3 \mathrm{~mm}$ SL, rio Santa Maria do Rio Doce. MBML 3590, 1(1), 61.0 mm SL, córrego Miracema on right side of road ES-080 from São Domingos do Norte to Colatina. MNRJ 37747, 1, $56.2 \mathrm{~mm}$ SL, same data as MBML 3590. Município de Itarana. MBML 763, 1, 26.4 mm SL, rio Santa Joana. Município de Linhares. MCP 42079, 1, 43.6 mm SL, rio Pequeno. MNRJ 9708, 1, not measured, Lagoa Juparanã. MZUSP 1461, 2, 74.6-80.0 mm SL, rio Doce. MZUSP 1560, 6, 52.6-63.4 $\mathrm{mm}$ SL, rio Doce. MZUSP 1622, 3, 47.7-75.7 mm SL, rio Doce. MZUSP 17065, 1, 53.0 mm SL, Lagoa do Aviso. MZUSP 17069, 1, 42.6 mm SL, Lagoa Nova. MZUSP 17073, 1, 75.4 mm SL, Lagoa Juparanã. MZUSP 75137, 11, 52.4-75.9 mm SL, rio Doce. ZUEC 3583, 4, 18.2-25.6 mm SL, córrego Rancho Alto, Reserva Florestal Vale do Rio Doce. Município de Pancas. MBML 1749,
2(1), 35.7-36.6 mm SL, córrego Ubá, tributary of rio Pancas. MBML 1836, 2(1), 49.6-22.9 mm SL, córrego Floresta, tributary of rio Pancas on fazenda Floresta Lajinha. MBML 2330, 2(2), 40.0-49.8 mm SL, córrego São Bento, tributary of rio Pancas in São Bento. Município de Santa Teresa. MZUSP 1562, 1, $64.2 \mathrm{~mm}$ SL, rio 25 de Julho. MZUSP 1629, 3, 57.6-62.8 mm SL, rio 25 de Julho. Minas Gerais State, rio Doce basin. Município de Frei Inocêncio. MCP 17771, 3, 30.5-30.9 mm SL, rio Suaçuí tributary of rio Doce, under bridge on road BR-116. Município de Mariléria. MZUSP 28972, 1, 58.9 mm SL. Lago Dom Helvécio, rio Doce Valley. MZUSP 28981, 15, 55.7-66.7 mm SL, Lagoa Carioca, rio Doce Valley. MZUSP 36648, 2, 57.1-67.8 mm SL, Lagoa Carioca, rio Doce Valley. MZUSP 107342, 5, 61.1-72.7 mm SL, Lagoa Carioca, Parque Estadual Rio Doce. Espírito Santo State, rio Barra Seca basin. Município de Linhares. MBML 48, 5(3), 41.5$60.4 \mathrm{~mm}$ SL, rio Ipiranga in Pontal do Ipiranga. MCP 17769, 4, 20.1-48.0 mm SL, Lagoa do Cupido on road BR-101, on northern limits of Reserva Biológica de Sooretama. MCP 17770, 1, 32.5 mm SL, coastal river on km 118 of road BR-101, near Reserva Biológica de Sooretama. Município de Sooretama. MBML 5114, 52(7), 59.2-81.4 mm SL, second pool on road ES-356 near bridge over rio Barra Seca, inside Reserva Biológica de Sooretama. MBML 5169, 5(2), 35.4-42.2 mm SL, rio Barra Seca under bridge on road ES-356 around the area of Reserva Biológica de Sooretama. MNRJ 5342, 7, 55.1-64.0 mm SL, rio Barra Seca, on road Linhares to São Mateus (in precary conservation state). MNRJ 17588, 22, 38.664.6 mm SL, rio Barra Seca. MNRJ 40099, 10, 46.2-76.5 mm SL, córrego Cupido, near road BR-101 inside Reserva Biológica de Sooretama. MNRJ 40103, 1, 44.1 mm SL, córrego Paraisópolis on its mouth in rio Barra Seca inside Reserva Biológica de Sooretama. MNRJ 40115, 6, 26.4-43.7 mm SL, rio Barra Seca under bridge on road ES-356 around the area of Reserva Biológica de Sooretama. MNRJ 40259, 54, 29.1-63.4 mm SL, same data as MBML 5169. Município de Jaguaré. MBML 5186, 1(1), 68.0 mm SL, rio Barra Seca on road between Nossa Senhora de Fátima and Vila Valério, around the area of Reserva Biológica de Sooretama. MNRJ 5324, 1, not measured, rio Cachimbau, on road Linhares to São Mateus. 
MNRJ 10916, 19, not measured, same data as MNRJ 5324. MNRJ 17215, 8, 51.2-60.2 mm SL, rio Jundiá, on road Linhares to São Mateus. MNRJ 17909, 10, 27.8-60.5 mm SL, rio Barra Seca, on road near boundary between Linhares and São Mateus. MNRJ 40036, 2, 45.2-64.7 mm SL, rio Barra Seca under bridge of road between Nossa Senhora de Fátima and Vila Valério, around the area of Reserva Biológica de Sooretama. MNRJ 53984, 6, 29.038.5 mm SL, same data as MNRJ 10916. Espírito Santo State, rio São Mateus basin. Município de Conceição da Barra. MBML 47, 1(1), 56.4 mm SL, córrego do Caboclo between Conceição da Barra and Itaúnas. MBML 3146, 6(2), 43.2-54.9 mm SL, córrego São Domingos. MBML 3189, 14(4), 45.0-57.5 mm SL, córrego São Domingos. Município de São Mateus. MBML 3101, 6(1), 43.7-62.5 mm SL, córrego São Domingos. MBML 5830, 4(3), 53.6-59.6 mm SL, Rio Preto do Sul in Guriri. MBML 5860, 1(1), 57.9 mm SL, rio Preto do Sul. MBML 5937, 3(3), 53.6-61.4 mm SL, rio Preto do Sul. MBML 5952, 1(1), $36.6 \mathrm{~mm} \mathrm{SL}$, rio Preto do Sul. MCP 17990, 15, 42.6-52.8 mm SL, rio Bamburral, tributary of rio São Mateus, on road ES-130 between Nova Venécia and São Mateus. MZUSP 51757, 1, 54.2 mm SL, rio São Mateus. Espírito Santo State, rio Itaúnas basin. Município de Pedro Canário. MBML 5883, 25(20), 39.9-58.5 mm SL, córrego da Estiva. MBML 5919, 2, 26.8-41.5 mm SL, tributary of rio Itaúnas upstream from córrego da Cruz, near road ES-209. MBML 5935, 10(10), 47.7$62.8 \mathrm{~mm}$ SL, tributary of rio Itaúnas upstream from córrego da Cruz, near road ES-209. MNRJ 5680, 6, 39.1-51.6 mm SL, fazenda Castro. MNRJ 12486, 1, 45.7 mm SL, fazenda Caboclo, northern Espírito Santo. MZUSP 93951, 33, 33.1-59.2 mm SL, rio Dourado, on road BR-101. Município de Pinheiros. MBML 1201, 4(1), 38,5-47.7 mm SL, rio Itauninhas. Bahia State, rio Buranhém basin. Município de Eunápolis. UFBA 4945, 1, 31.1 mm SL, rio Buranhém, near the small village of Colônia. Bahia State, rio Itaúnas basin. Município de Mucuri. MBML 4728, 1, 21.2 mm SL, córrego Douradão on road Picadão da Bahia. MBML 4731, 3, 35.2-53.7 mm SL, córrego Douradão on road Picadão da Bahia. MZUSP 93950, 2, 41.1-41.4 mm SL, unnamed stream on road BR-418. Bahia State, rio Mucuri basin. Município de Mucuri. MBML 3288, 3(2), 66.0-67.4 mm SL, rio Mucuri, close to mangrove marginal vegetation. MNRJ 22862, 1, $20.0 \mathrm{~mm} \mathrm{SL}$, rio Mucuri on road BR-101. MNRJ 22944, 45, 25.2-47.5 mm SL, rio Mucurizinho, near road BR-101 in município de Itabatan. MZUSP 51804, 135, 21.4-50.9 mm SL, rio Mucuri, between river estuary and município de Argolo. UFBA 5036, 6, 32.6-70.8 mm SL, Itabatã, rio Mucuri, on BR-101. Bahia State, rio Peruípe basin. Município de Nova Viçosa. MBML 3831, 6(6), 53.4-68.9 mm SL, headwater lake of a tributary of rio Peruípe, near road BR418. MCP 17979, 12, 20.0-52.8 mm SL, stream tributary of rio Peruípe on road between BR-101 and Caravelas, about $14 \mathrm{~km}$ west from BR-101. MNRJ 2869, 9, not measured, headwater lake of a tributary of rio Peruípe, near road BR-418. MZUSP 54778, 10, 36.9-58.4 mm SL, stream tributary of rio Peruípe on road between BR-101 and Caravelas, about 14 km west from BR-101. MZUSP 101123, 2, 37.4-55.5 mm SL, stream near Nova Viçosa. Bahia State, rio Itanhém basin. Município de Alcobaça. MCP 36721, 2, 30.7-30.9 mm SL, stream tributary of rio Itanhentinga, in Arraial Pouso Alegre locality. Bahia State, rio Jucuruçu basin. Município de Itamaraju. MCP 17981, 3, 33.9-49.3 mm SL, rio Jucuruçu in a farm upstream from município de Itamaraju. Município de Teixeira de Freitas. UFBA 5063, 1, 29.3 mm SL, rio Itanhém, in the small village of Prainha, near BR-101. UFBA 5075, 7, 28.5-43.3 mm SL, rio Itanhentinga, on BR-101. Bahia State, rio dos Frades basin. Município de Itabela. MCP 17980, 6, 28.9-
54.6 mm SL, rio dos Frades on road BR-101 between Guaratinga and Monte Pascoal. MZUSP 54776, 4, 35.3-44.9 mm SL, rio dos Frades on road BR-101 between Guaratinga and Monte Pascoal.

\section{Discussion}

Tetragonopterus doceanus was transferred to Moenkhausia doceana by Eigenmann (1910:437). The specific epithet "doceanus" is a reference to the rio Doce, primarily type locality of the species. Moenkhausia doceana has the diagnostic features for the genus proposed by Eigenmann (1917) and herein we keep with this traditional definition, pending a more comprehensive phylogenetic context.

Traditionally, Moenkhausia doceana has been considered a member of $M$. chrysargyrea species group since Géry (1977), a group of species with seven or more scales above lateral line to dorsal-fin origin, five or more scales below the lateral line to pelvic-fin origin, and a relatively deep body. This group originally included 12 species: $M$. chrysargyrea (Günther), M. comma Eigenmann, M. doceana, M. eigenmanni Géry, $M$. jamesi, $M$. justae, $M$. metae Eigenmann, M. miangi Steindachner, M. naponis Böhlke, $M$. pittieri Eigenmann, $M$. surinamensis Géry, and $M$. tridentata (Géry, 1977: 446-447). Subsequently, more species can be assigned to the $M$. chrysargyrea group: $M$. dasalmas Bertaco, Jerep \& Carvalho, $M$. dorsinuda, $M$. levidorsa, $M$. margitae, $M$. moisae Géry, Planquette \& Le Bail, $M$. pankilopteryx Bertaco \& Lucinda, and M. pirauba. Moenkhausia doceana differs from all congeners included in the $M$. chrysargyrea-group by having 4-7 maxillary teeth (vs. 3 or less in remaining species of group, except $M$. dasalmas and $M$. naponis); from $M$. dasalmas and $M$. naponis by having 29-34 branched anal-fin rays and an oval humeral spot (vs. 28 or less branched anal-fin rays and a vertical humeral spot in both species).

Moenkhausia doceana is very similar to M. margitae, as mentioned by Zarske \& Géry (2001), based on the body form and color pattern, with a horizontally elongate black humeral spot. It differs of $M$. margitae by presenting 4-7 maxillary teeth and the caudal peduncle with a faint dark spot in the hypural plate area (vs. 1-2 maxillary teeth and no marks dark over the caudal peduncle).

In the Northeastern Mata Atlântica ecorregion, three Moenkhausia species are found: $M$. costae (Steindachner), M. diamantina Benine, Castro \& Santos, and M. doceana. Moenkhausia doceana differs from $M$. costae mainly by the hyaline caudal fin (vs. a conspicuous black stripe extending from anal-fin origin to tip caudal-fin upper lobe); from $M$. diamantina by having anal fin with 29 or more branched rays ( $v s$. anal fin with 28 or less branched rays in M. diamantina).

In recent descriptions of Moenkhausia species, there are usually comments on putative relationships of the new species described with its congeners; and this information is primarily based on one or a few shared characters among 
the taxa based on groups of Géry (1977). Although there are few published morphological hypotheses testing the relationships between Characidae species, we herein address some tests, in order to contribute to phylogenetic knowledge within the group. Following the protocol of Mirande (2010) for the Characidae, we tentatively discuss the results for $M$. doceana in this approach.

Phylogenetic placement of Moenkhausia doceana in Mirande's (2010) context results in its relationship within a clade including Tetragononopterus argenteus Cuvier, Gymnocorymbus ternetzi (Boulenger), Stichonodon insignis (Steindachner), Stethaprion erythrops Cope and Poptella paraguayensis (Eigenmann). Moenkhausia xinguensis (Steindachner), type species of genus, is closely related to $M$. sanctaefilomenae (Steindachner) plus Bario steindachneri (Steindachner): (M. xinguensis ( $M$. sanctaefilomenae, B. steindachneri)). This last one monophyletic clade represents the sister group to $M$. doceana clade. The synapomorphies recognized for $M$. doceana clade are also present in other small characid groups. In this way, proposals involving taxonomic changes are premature in this moment, and more Moenkhausia species should be included in future analyses, because few species of Moenkhausia were considered in this framework (four species in Mirande, 2010 - M. dichroura (Kner), M. cf. intermedia Eigenmann, M. sanctaefilomenae (Steindachner), plus $M$. doceana herein added).

Mariguela et al. (2013) presented a molecular phylogenetic analysis for some Moenkhausia species (29 of 75 species, not including $M$. doceana), and recognized some monophyletic clades, but their conclusions also reinforce a non-monophyletic genus, and an extensive revision of the whole group is required.

Eigenmann (1917) stated Moenkhausia as distinct from Tetragonopterus Cuvier regarding the lateral line direction (i.e., line straight vs. slightly curved downwards). Reis (2003) restricted Tetragonopterus to two species (T. argenteus and T. chalceus Spix \& Agassiz), and more recently new species have been proposed (e.g., Melo et al., 2011; Silva \& Benine, 2011; Silva et al., 2013). Melo et al. (2011) discussed the presence of three supraneurals and one branched laterosensory canal on the sixth infraorbital bone as putative synapomorphies for Tetragonopterus. This last character was also used by Mirande (2010, char. 76). Moenkhausia doceana has 3-4 supraneurals (mode 4) and no branched laterosensory canal on sixth infraorbital, and in this way the species does not fit in a monoplyletic Tetragonopterus clade (sensu Melo et al., 2011).

Three lots of Moenkhausia doceana (MZUSP 1404, 1, 79.1 mm SL; MZUSP 1625, 14, 64.3-79.5 mm SL; and MZUSP 16374, 5, 62.0-74.9 mm SL) were collected by E. Garbe in Porto Cachoeiro locality, Espírito Santo State. Porto Cachoeiro was the name given to Santa Leopoldina between 1890 and 1911. This area is drained by rio Santa Maria da Vitória basin, a costal river drainage in northeastern Espírito Santo. Several collecting efforts were directed to the whole area, but no record of this species was obtained. Thus, as those are very ancient records and as we do not have any recent record of $M$. doceana for the rio Santa Maria da Vitória basin, we opted not to include this river basin in the distributional area of the species.

A reappraisal of very old described species should be encouraged today. In a study such as the one presented herein, we had the chance to increment the diagnosis for such a taxon, improve the knowledge on its distribution, and provide phylogenetic information, primordial for several other scientific areas. As mentioned above, approximately one-half of Moenkhausia species were described before 1950, and many of these were not clearly diagnosed. Indeed, the desired condition is a complete taxonomic revision of all these taxa. Nowadays, for "catch-all” genera (sensu Bertaco \& Lucinda, 2006) such as Astyanax (ca. 140 species), Hemigrammus (54 species), Hyphessobrycon (132 species), and Moenkhausia (75 species) (Eschmeyer, 2014), it is very difficult to assess their taxonomic compositions in a single work including all species of each genera, thus redescriptions are encouraged for many of these species.

As presented by Malabarba et al. (2012) and Weiss et al. (2012), the conserved form within the Characidae, a long period of evolution of the group and its great diversity are the most challenging factors for understanding the relationships among small characids. Characters should be continuously assessed to address the significance in delimiting groups within the Characidae, mainly in the Tetragonopterinae (sensu Mirande, 2010) and in the informal clades of Mirande (2010) (e.g., Bryconops clade, Bramacharax clade, Pseudochalceus clade, Hyphessobrycon luetkenii clade, Astyanax paris clade, Astyanax clade, Bryconamericus sclerioparius clade), as many features are relatively widespread among these small characids. Taxonomic changes in species-rich genera as Moenkhausia, grounded in phylogenetic analysis, are necessary and expected in the next years, according to hypotheses of monophyletic groups.

Comparative material. For all type specimens mentioned herein, including some junior synonyms of Moenkhausia and other taxa, the names are according to the original description (nominal taxon). Astyanax simulatus: USNM 167811, 2 syntypes, 47.5-51.0 mm SL, Peru, creek at Puerto Bermudez, río Pichis, río Marañon system. Moenkhausia agnesae: SMF 7238, holotype, $66.9 \mathrm{~mm}$ SL, Brazil, near Tabatinga, igarapé Preto, collateral of the upper Amazon, about around $60 \mathrm{~km}$ downstream from Letícia. Moenkhausia aurantia: UFRGS 13619, holotype, 40.6 mm SL, Brazil, Goiás, Nova Roma, córrego Kavanca at fazenda Kavanca, upper rio Tocantins basin. Moenkhausia bonita: MZUSP 79805, holotype, 34.0 mm SL, Brazil, Mato Grosso do Sul, Bonito, rio Baía Bonita, Parque Baía Bonita, ‘Aquário Natural,’ upper rio Miranda, rio Paraguay basin. Moenkhausia browni: FMNH 52732, holotype, 49.4 mm SL, Guyana, creeks about Arutaima, Potaro River. Moenkhausia ceros: MCZ 49161, holotype, 37.0 mm SL, Brazil, Amazonas, Lake Hyanuary [= Paraná do Janauari, Amazonas]. Moenkhausia chrysargyrea leucopomis: ANSP 39330, holotype, 72.0 mm SL, Guyana, Rupununi River. Moenkhausia 
comma: MCZ 20972, 2 syntypes, $60.7 \mathrm{~mm} \mathrm{SL} \mathrm{(one} \mathrm{specimen} \mathrm{is}$ completely destroyed), Brazil, Amazonas, Lago Cudajas [Lago Badajos]. Moenkhausia cosmops: MZUSP 93494, holotype, 42.4 mm SL, Brazil, Mato Grosso, Sapezal, córrego Vinte e Cinco de Maio, near its mouth at the rio Papagaio. Moenkhausia dasalmas: UFRGS 11221, holotype, 42.9 mm SL, Brazil, Goiás, Cavalcante, tributary of the rio das Almas about $8 \mathrm{~km}$ North of Cavalcante on GO-241, upper rio Tocantins, between Cavalcante and Minaçu. Moenkhausia diamantina: MNRJ 21995, 2 of 17 paratypes, 57.258.2 mm SL, Brazil, Bahia, Lençóis, foz do rio Toalhas, rio Paraguaçu basin. Moenkhausia dichrourus intermedius: MCZ 20762, 2 syntypes, 32.0-49.0 mm SL, Brazil, Amazonas, Tabatinga [rio Solimões at Tabatinga (aka Sapurara) and environs]. Moenkhausia diktyota: MZUSP 62614, holotype, $52.3 \mathrm{~mm}$ SL, Brazil, Amazonas, rio Negro, igarapé at São João, near Santa Isabel do Negro. Moenkhausia eigenmanni: USNM 198640, holotype, $49.3 \mathrm{~mm} \mathrm{SL}$, Colombia, Restrepo, río Manacacias into upper río Meta. Moenkhausia georgiae: ZMA 104223, holotype, 68.6 mm SL, French Guiana, middle Mana River, between "SautChien" and "Saut-Topi-Top". Moenkhausia heikoi: MZUSP 83536, holotype, 46.5 mm SL, Brazil, Pará, rio Iriri, a left-hand tributary of the Rio Xingú well above Altamira, among rocks in $2.5 \mathrm{~m}$ depth at the edge of an island between Rio Novo and Igarapé Grota, ca. $10 \mathrm{~km}$ below mouth of rio Novo. Moenkhausia hemigrammoides: ZMA 104227, holotype, $40.0 \mathrm{~mm}$ SL, Suriname, Marowije, Matoekasi creek at Weyne, on the road Albina-Moengo. Moenkhausia hysterosticta: MCP 32559, holotype, $42.9 \mathrm{~mm}$ SL, Brazil, Tocantins, rio Tocantins, Ipueiras. Moenkhausia inrai: ZMA 120798, 8 paratypes, 45.4-59.3 mm SL, French Guiana, Maroni, Antecume Pata, Haut Maroni. Moenkhausia latissimus: USNM 120277, 3 syntypes, 44.2-66.6 mm SL, Brazil, Tabatinga, Thayer Expedition to Brazil. Moenkhausia lepidura madeirae: ANSP 39224, holotype, 43.0 mm SL, Brazil, Rondônia, Porto Velho, tributary of rio Madeira near Porto Velho. Moenkhausia lepidura ocoae: ANSP 70497, holotype, 30.0 mm SL, Colombia, río Ocoá, south of Villavicencio, río Meta basin. Moenkhausia lepidurus gracilimus: USNM 120279, 4 syntypes, 41.4-45.7 mm SL, Brazil, Amazonas, Serpa [now Itacoatiara], Thayer Expedition to Brazil. Moenkhausia lepidurus latus: USNM 120278, 4 syntypes, 43.2-50.4 mm SL, Brazil, Pará, rio Tapajós basin, Thayer Expedition to Brazil. Moenkhausia levidorsa: INPA 16774, holotype, 59.9 mm SL, Brazil, Mato Grosso, Núcleo Aripuanã, igarapé do Aeroporto, Furo Bahia, above cachoeira de Dardanelos. Moenkhausia loweae: MZUSP 44560, holotype, 51.7 mm SL, Brazil, Rio das Mortes at Xavantina. Moenkhausia margitae: MTD F 17256, holotype, 63.7 mm SL, Peru, Ucayali, quebrada on road Campo VerdeNueva Requena (about half way). Moenkhausia metae: FMNH 55214, 4 paratypes, 46.9-51.9 mm SL, Colombia, Villavicencio, headwaters of the río Meta. Moenkhausia miangi: NMW 56300, 1 syntype, $87.0 \mathrm{~mm}$ SL, Venezuela, Miang, on the Venezuela border. NMW 56298, 2 syntypes, 71.0-78.1 mm SL, same data as NMW 56300. Moenkhausia naponis: USNM 164067, holotype, 53.2 mm SL, Ecuador, headwaters of río Arajuno. Moenkhausia nigromarginata: MZUSP 45289, 1 of 5 paratype, 39.5 mm SL, Brazil, Mato Grosso, small stream tributary to rio Cravari near the road MT-170, about $10 \mathrm{~km}$ N of Campo Novo do Parecis, río Tapajós basin. Moenkhausia pankilopteryx: MZUSP 88258, holotype, 86.3 mm SL, Brazil, Pará, rio Itacaiúnas (rio Tocantins drainage), about $10 \mathrm{~km}$ east of road N-4, Serra dos Carajás at Igarapé. Moenkhausia petymbuaba: MZUSP 85577, holotype,
55.4 mm SL, Brazil, Pará, rio Curuá, Serra do Cachimbo, SantarémCuiabá Road. Moenkhausia phaeonota: MZUSP 13793, holotype, 32.6 mm SL, Brazil, Mato Grosso, shores of an island "below Rio dos Peixes”, rio Arinos. Moenkhausia pirauba: MZUSP 97741, holotype, 69.8 mm SL, Brazil, Mato Grosso, Campinápolis, rio Sucuri, tributary of rio Culuene, rio Xingu basin. Moenkhausia pittieri: CAS 62059, holotype, $44.1 \mathrm{~mm}$ SL, Venezuela, Concejo, río Tiquirito. Moenkhausia pyrophthalma: MZUSP 45290, 1 of 7 paratype, 30.4 mm SL, Brazil, Mato Grosso, stream crossing the road between Água Boa and Cocalinho, $13 \mathrm{~km}$ $\mathrm{W}$ of the point where the road reaches rio das Mortes, rio AraguaiaTocantins basin. Moenkhausia robertsi: USNM 200427, holotype, $48.1 \mathrm{~mm}$ SL, Peru, Iquitos, upper Amazon, region surrounding Iquitos. Moenkhausia shideleri: FMNH 52961, holotype, 48.9 mm SL, Guyana, Bartica. Moenkhausia takasei: USNM 198136, holotype, 32.6 mm SL, Brazil, Pará, creek near Belém do Pará, rio Guamá basin, lower Amazon. Tetragonopterus collettii: MCZ 20843, 42 syntypes, 27.1-40.9 mm SL, Brazil, Pará, Óbidos, [rio Amazonas at Óbidos]; NMW 57382, 5 syntypes, 27.4-31.4 mm SL, same data as MCZ 20843; NMW 57379, 3 syntypes, 39.2-49.9 mm SL, Brazil, Hyavary [rio Javari (tributary of rio Solimões) at the Peruvian-Brazilian border]. Tetragonopterus copei: MCZ 89960, 6 syntypes, 29.6-33.3 mm SL, Brazil, Pará, Santarém, rio Amazonas; NMW 5738, 5 syntypes, 22.0-35.5 mm SL, same data as MCZ 89960. Tetragonopterus costae: NMW 57396, 25 syntypes, 25.7-37.5 mm SL, Brazil, Joazeiro [Juazeiro, Bahia], rio São Francisco; NMW 57397, 3 syntypes, 37.5-40.0 mm SL, same data as NMW 57396; NMW 57398, 24 syntypes, 23.0-35.6 mm SL, Brazil, Palmeira and Sambaia. Tetragonopterus dichrourus: NMW 56219, 4 syntypes, 34.7-54.7 mm SL, Brazil, Caiçara; NMW 57593, 2 syntypes, 47.8-49.4 mm SL, same data as NMW 56219. Tetragonopterus xinguensis: NMW 57826, holotype, $37.3 \mathrm{~mm}$ SL, Brazil, rio Xingu.

\section{Acknowledgments}

We are grateful to Priscila Camelier (MZUSP) and Angela Zanata (UFBA) for information on Moenkhausia doceana in the Bahia State; George Mattox (UFSCAR), Vinicius Bertaco (FZB), and an anonymous reviewer for valuable suggestions on the manuscript; Francisco Langeani (DZSJRP) for laboratorial support. For loans, exchange of specimens and/or courtesies extended during visits to their institutions we thank John Lundberg and Mark Sabaj Pérez (ANSP), David Catania and Jon Fong (CAS), Carlos Lucena and Margarete Lucena (MCP), Sonia Fisch-Muller and Raphael Covain (MHNG), Paulo Buckup and Marcelo Britto (MNRJ), Gabsi Zora and Patrice Pruvost (MNHN), Osvaldo Oyakawa, Manoela Marinho and Michel Gianeti (MZUSP), Helmut Wellendorf (NMW), Tilman Alpermann (SMF), Richard Vari, Sandra Raredon and Jeffrey Clayton (USNM), Luiz Malabarba (UFRGS). FRC is supported by a postdoctoral fellowship from FAPESP (Fundação de Amparo à Pesquisa do Estado de São Paulo) (procs. \#2011/11422-8 and \#2012/03404-2). Part of the analysis of the syntypes was possible due to a scholarship program for Sandwich Ph.D. of CNPq for FRC (proc. \#201513/2009-9). 


\section{Literature Cited}

Abell, R., M. L. Thieme, C. Revenga, M. Bryer, M. Kottelat, N. Bogutskaya, B. Coad, N. Mandrak, S. L. Balderas, W. Bussing, M. L. J. Stiassny, P. Skelton, G. R. Allen, P. Unmack, A. Naseka, R. Ng, N. Sindorf, J. Robertson, E. Armijo, J. Y. Higgins, T. J. Heibel, E. Wikramanayake, D. Olson, H. L. López, R. E. Reis, J. G. Lundberg, M. H. S. Pérez \& P. Petry. 2008. Freshwater ecoregions of the world: a new map of biogeographic units for freshwater biodiversity conservation. Bioscience, 58: 403-414.

Bertaco, V. A., F. C. Jerep \& F. R. Carvalho. 2011. New species of Moenkhausia Eigenmann (Ostariophysi: Characidae) from the upper Rio Tocantins basin in central Brazil. Neotropical Ichthyology, 9: 57-63.

Bertaco, V. A. \& P. H. F. Lucinda. 2006. Moenkhausia pankilopteryx, a new species from rio Tocantins drainage, Brazil (Ostariophysi: Characiformes, Characidae). Zootaxa, 1120: 57-68.

Burns, J. R. \& S. H. Weitzman. 1996. Novel gill-derived gland in the male swordtail characin, Corynopoma riisei (Teleostei: Characidae: Glandulocaudinae). Copeia, 1996: 627-633.

Carvalho, F. R., V. A. Bertaco \& F. C. Jerep. 2010. Hemigrammus tocantinsi: a new species from the upper rio Tocantins basin, central Brazil (Characiformes: Characidae). Neotropical Ichthyology, 8: 247-254.

Carvalho, F. R., G. C. Jesus \& F. Langeani. 2014. Redescription of Hyphessobrycon flammeus Myers, 1924 (Ostariophysi: Characidae), a threatened species from Brazil. Neotropical Ichthyology, 12: 247-256.

Eigenmann, C. H. 1910. Catalogue of the fresh-water fishes of tropical and south temperate America. In: Scott, W. B. (Ed.). Reports of the Princeton University Expeditions to Patagonia 1896-1899. Princeton, N. J., 3: 375-511.

Eigenmann, C. H. 1917. The American Characidae - I. Memories of the Museum of Comparative Zoölogy, 43: 1-102.

Eschmeyer, W. N. (Ed). 2014. Catalog of Fishes: Genera, Species, References. Available from: http://research.calacademy.org/ research/ichthyology/catalog/fishcatmain.asp (13 Jan 2014).

Fink, W. L. \& S. H. Weitzman. 1974. The so-called cheirodontin fishes of Central America with descriptions of two new species (Pisces: Characidae). Smithsonian Contributions to Zoology, 172: 1-46.

Géry, J. 1977. Characoids of the World. T. F. H. Publications, Neptune City, NJ.

Goloboff, P. A., J. S. Farris \& K. C. Nixon. 2008. TNT, a free program for phylogenetic analysis. Cladistics, 24: 774-786. Version 1.11. Available from: http://www.zmuc.dk/public/ phylogeny/TNT/ (03 Nov 2013).

Lima, F. C. T., P. A. Buckup, N. A. Menezes, C. A. S. Lucena, Z. M. S. Lucena, M. Toledo-Piza \& A. Zanata. 2007. Família Characidae: gêneros incertae sedis. Pp. 44-62. In: Buckup, P. A., N. A. Menezes \& M. S. Ghazi. Catálogo das espécies de peixes de água doce do Brasil. Série livros 23, Museu Nacional, Universidade Federal do Rio de Janeiro, Rio de Janeiro.

Lima, F. C. T., L. R. Malabarba, P. A. Buckup, J. F. Pezzi da Silva, R. P. Vari, A. Harold, R. Benine, O. T. Oyakawa, C. S. Pavanelli, N. A. Menezes, C. A. S. Lucena, M. C. S. L. Malabarba, Z. M. S. Lucena, R. E. Reis, F. Langeani, L. Casatti, V. A. Bertaco, C. Moreira \& P. H. F. Lucinda. 2003. Genera Incertae Sedis in Characidae. Pp. 106-169. In: Reis, R. E., S. O. Kullander \& C. J. Ferraris Jr. (Eds.). Check List of the freshwater fishes of South and Central America. Porto Alegre, Edipucrs.
Malabarba, L. R., V. A. Bertaco, F. R. Carvalho \& T. O. Litz. 2012. Revalidation of the genus Ectrepopterus Fowler (Teleostei: Characiformes), with the redescription of its type species, E. uruguayensis. Zootaxa, 3204: 47-60.

Mariguela, T. C., R. C. Benine, K. T. Abe, G. S. Avelino \& C. Oliveira. 2013. Molecular phylogeny of Moenkhausia (Characidae) inferred from mitochondrial and nuclear DNA evidence. Journal of Zoological Systematics and Evolutionary Research, 51: 327-332.

Melo, B. F., R. C. Benine, T. C. Mariguela \& C. Oliveira. 2011. A new species of Tetragonopterus Cuvier, 1816 (Characiformes: Characidae: Tetragonopterinae) from the rio Jari, Amapá, northern Brazil. Neotropical Ichthyology, 9: 49-56.

Mirande, J. M. 2009. Weighted parsimony phylogeny of the family Characidae (Teleostei: Characiformes). Cladistics, 2009: 573-613.

Mirande, J. M. 2010. Phylogeny of the family Characidae (Teleostei: Characiformes): from characters to taxonomy. Neotropical Ichthyology, 8: 385-568.

Ottoni, F. P., A. Q. Lezama, M. L. Triques, E. N. Fragoso-Moura, C. C. T. Lucas \& F. A. R. Barbosa. 2011. Australoheros perdi, new species (Teleostei: Labroidei: Cichlidae) from the lacustrine region of the Doce River Valley, southeastern Brazil, with biological information. Vertebrate Zoology, 61: 137-145.

Reis, R. E. 2003. Subfamily Tetragonopterinae (Characins, tetras). Pp. 215. In: Reis, R. E., S. O. Kullander \& C. J. Ferraris Jr. (Orgs.). Check List of the freshwater fishes of South and Central America. Porto Alegre, Edipucrs.

Reis, R. E., S. O. Kullander \& C. J. Ferraris-Jr (Orgs.). 2003. Check List of the Freshwater Fishes of South and Central America. Porto Alegre, Edipucrs.

Sarmento-Soares, L. M. \& R. F. Martins Pinheiro. 2013. A fauna de peixes na REBIO Córrego Grande e seu entorno direto, Espírito Santo, Brasil. Boletim do Museu de Biologia Mello Leitão, 31: 25-57.

Silva, G. S. C. \& R. C. Benine. 2011. A new species of Tetragonopterus Cuvier, 1816 (Characiformes, Characidae, Tetragonopteridae) from the upper rio Araguaia, central Brazil. Zootaxa, 2911: 50-56.

Silva, G. S. C., B. F. Melo, C. Oliveira \& R. C. Benine. 2013. Morphological and molecular evidence for two new species of Tetragonopterus (Characiformes: Characidae) from central Brazil. Journal of Fish Biology, 82: 1613-1631.

Steindachner, F. 1877. Die Süsswasserfische des südöstlichen Brasilien (III). Sitzungsberichte der Kaiserlichen Akademie der Wissenschaften. Mathematisch-Naturwissenschaftliche Classe, 74: 559-694.

Taylor, W. R. \& G. C. Van Dyke. 1985. Revised procedures for staining and clearing small fishes and other vertebrates for bone and cartilage study. Cybium, 9: 107-119.

Weitzman, S. H. 1962. The osteology of Brycon meeki, a generalized Characidae fish, with an osteological definition of the family. Stanford Ichthyogical Bulletin, 8, 1-77.

Zarske, A. \& J. Géry. 2001. Moenkhausia margitae sp. n. - eine neue Tetra-Art aus dem Stromgebiet des Rio Ucayali in Peru (Teleostei: Characiformes: Characidae). Zoologische Abhandlungen; Staatliches Museum für Tierkunde in Dresden, 51: 5-14.

Zarske, A. \& J. Géry. 2002. Moenkhausia dorsinuda sp. n. - ein neuer interessanter Salmler (Teleostei, Characiformes, Characidae) aus dem Einzugsgebiet des Río Iténez in Bolivien. Zoologische Abhandlungen; Staatliches Museum für Tierkunde in Dresden, 52: 11-21. 
Weiss, F. E., L. R. Malabarba \& M. C. Malabarba. 2012. Phylogenetic relationships of Paleotetra, a new characiform fish (Ostariophysi) with two new species from the EoceneOligocene of south-eastern Brazil. Journal of Systematics Palaeontology, 10: 73-86.

Submitted January 13, 2014 Accepted May 4, 2014 by Luiz R. Malabarba Published June 30, 2014 